\title{
Generations and Globalization: Youth, Age, and Family in the New World Economy
}

\author{
Edited by Jennifer Cole and Deborah Durham \\ Bloomington: Indiana University Press. 2007. \\ ISBN: 978-0253218704, \$29.28, 240 pages.
}

\author{
Barbara A. Mitchell, Ph.D \\ Simon Fraser University \\ mitchelo@sfu.ca
}

Written primarily by cultural anthropologists, the collection of essays presented in this volume provides a fresh analytical perspective to the study of age, intergenerational relationships, and globalization. Critical of previous anthropological studies that polarize "the global" and the "local," a major theme woven throughout the book is the necessity of connecting structural demographic changes (e.g., population aging, the transnational migration of workers) to the role that individual agency and families play in shaping globalization and processes of inequality. As such, all of the papers in this book emphasize the ways in which intergenerational transmission and social reproduction inherent in family exchanges are critical to the movement of people through their life cycles and to the regeneration of households and the social world.

Through this lens, the authors convincingly contextualize broader macrolevel questions of domestic labour, capital, the management and movement of populations, and the production of commodities. They accomplish this task by providing vignettes and case studies drawn from selected countries throughout the world (China, Mexico, Madagascar, Botswana, India, and Western Europe). A particular strength of this book is that the various stages of the life course - childhood, youth, adulthood, and old age - are not viewed as fixed or separate categories. Instead, the authors make the argument that studies of age need to transcend a single age group or cohort focus in order to examine the complex interplay between intergenerational relations and wider historical and social processes.

The relevance and application of this theme is reflected in chapters that address the salience of reciprocity between the generations as they engage in productive activity within changing environments. For example, 
Magazine and Sanchez (Chapt. 2) explore how the concept of ayuda or a child's repayment of the nurture received during childhood continues to structure transnational cycles of exchange. Notably, when Mexican children live abroad in California as migrant workers, they continue to give back to their families by sending home most of their earnings in the form of remittances. This new version of childhood not only sustains family relationships and insures the inheritance of property later on, but also allows the local Mexican economy to flourish. This is evidenced in a small Mexican village called San Pedro, Tlalcuapan. Here we see the massive construction of new houses (remodeled after suburban California homes and complete with automatic garage door openers) and the undertaking of various public work projects. Another benefit is that parents are no longer obligated to send their sons and daughters to local cities to work as domestic servants, a situation viewed as less than ideal, since it can be abusive and it prevents children from attending school.

Conversely, in Lamb's chapter (Chapt. 5), it is shown that South Asian seniors migrate to the United States with the expectation of receiving a reciprocation of the care they gave their children who now live there. However, they arrive only to find that their children are unable to provide care due to long working hours. As a result, South Asian immigrants must take advantage of state services and use these services to forge new identities as American seniors, adopting models of independent aging. This notion that new forms of work and programs devised by NGOs and the government intervene in reciprocal exchanges is also observed in Botswana. For example, youth are "empowered" by social policies and initiatives that redefine their contributions to society. In this way, their mode of maturing and caring relations becomes transformed (Durham, Chapt. 4). Livingston (Chapt. 6) also finds that the model of care embraced by disabled elderly conflicts with the model proposed by international NGOs, which creates intergenerational strains, especially between mothers and daughters. Generally, we learn throughout the volume how the elderly and youth in diverse nations are actively negotiating unique interdependencies as new models of intergenerational caring arise.

Indeed, many papers demonstrate the tension between intergenerational reciprocity and competing values under neoliberal economic and state policies. These policies champion individual responsibility and the achievement of knowledge in a socially integrated, competitive global economy. This includes youth, middle-age wage earners, "third age" (5574 years), physically able workers, and "fourth age" elders needing care, according to Greenberg and Muehlebach (Chapt. 7). These authors apply these ideas to Western Europe and the retrenchment and dismantling of 
the welfare state, and how states govern and care for their populations. For example, they note how the deferral of retirement via active aging paves the way for the management of welfare and labour forces according to a new, naturalized individual and collective life cycle. However, with changing pension regulations and the Europe-wide raising of retirement ages, many middle-class worker find themselves risking poverty and exclusion because they are simultaneously too old to work and too young to receive state pensions.

Moreover, the rise of global consumerism fosters new values that introduce new lifestyles and conflicts that can disrupt the flow of generational exchanges. In Madagascar, as examined by Cole (Chapt. 3), consumer goods such as fashionable clothes and cell phones have flooded the country, which creates novel forms of self-development among young urbanites. Further, changes in the economy and opportunities for young women to sell transactional sex contribute to a different means for achieving adulthood, which is measured more in terms of access to commodities than productive labour. For girls, improving their status and value entails selling their sexuality to men, who include European tourists, wealthy Indian traders, and local men. However, unlike previous historical periods, these transformations disrupt social hierarchies along the axes of generation and gender and splinter local families. For example, young women in the port town of Tamatave have better options for earning a living than their male counterparts. Since jobs for men are hard to secure, women end up supporting men, a practice that thwarts the power of urban young men and disrupts long-standing norms of "proper" gendered, family, and kinship relations.

Similarly, in Woronov's essay (Chapt. 1), we observe the arms of global consumerism extending into Chinese childrearing practices through American education ideological and marketing efforts. This is illustrated by the practice of Chinese parents from the growing urban, middle class population to eagerly purchase advice manuals, such as "Harvard Girl Liu Yiting" and "Quality Education." In recent years, well over a million copies of each of these books were sold in China, spawning follow-up volumes as well as countless imitators. Chinese parents buy these books with the hope that they will raise a "high quality" child who is well prepared to succeed in the new, highly competitive economy. This goal is particularly desirable given the state's one-child only policy that was first implemented in the early 1980s. It also allows offspring to move beyond China's borders into global spaces defined by ivy-league institutions such as Harvard.

Overall, the papers in the volume should be of value to those interested in age and generational relations, population change, and globalization processes. Although at times some readers may find some conceptual 
material repetitive, it is well worth the read for its insightful analyses. In particular, the case studies presented throughout the book bring to life the fact that globalization does not take place "out there." Rather, it takes place as individuals continuously make decisions about specific relationships and through their struggle to shape livable environments in the present and future. Indeed, we are aptly reminded that it is as much in the home and in families, as in financial markets and international agreements, that the reproduction - and regeneration - of populations and societies takes place. 